\title{
Радянсько-фінська війна
}

\section{Світлана Донченко, Дніпровський державний технічний університет}

Увесь період існування Радянського Союзу та перші роки незалежності України ніхто не писав і не говорив про військовий конфлікт взимку 1939-1940рр. Причина у стратегічній поразці величезного СРСР у війні з маленькою Фінляндією. У Радянському Союзі намагалися створити таке поняття, як «радянський народ», відбувалося переселення і змішання великої кількості людей на всьому просторі СРСР. Тому ніхто ніколи не визначав учасників подій за національністю або територіальним розташуванням. Не виділялися й українці. Лише коли Україна стала незалежною, виникла потреба з'ясувати участь українців у радянсько-фінській війні та їх роль. Під час радянсько-фінської війни Північно-Західним фронтом командував майбутній Маршал і Герой Радянського Союзу, українець Тимошенко Семен Костянтинович. Майбутній Маршал і Герой Радянського Союзу, українець Кулик Григорій Іванович, як заступник наркома оборони СРСР, брав участь у підготовці армійських і артилерійських частин до радянсько-фінської війни. Командиром 70-ї дивізії був українець Кирпонос Михайло Петрович. Приймав участь у бойових діях льотчик-ас і Герой Радянського Союзу, українець Кравченко Григорій Пантелійович. Майбутній Маршал і Герой Радянського Союзу, українець Москаленко Кирило Семенович, під час радянсько-фінської війни був начальником артилерії 51-ї Перекопської стрілецької дивізії Одеського військового округу. Майбутній генерал-полковник танкових військ і Герой Радянського Союзу, українець Кравченко Андрій Григорович, під час війни був начальником штабу 173-ї мотострілецької дивізії. У трьохмісячному конфлікті загинуло майже 40 тисяч українців. Серед тих, хто воював у цій війні та отримав найвищу нагороду - орден Леніна - Василь Петренко з Полтавщини. На боці СРСР у війні брали участь дві дивізії, які комплектувались в Україні. Це 44-та та 70-та стрілецькі дивізії. Перша 3 них потрапила в оточення і майже вся загинула, намагаючись вирватись 3 фінського кільця. Ті, хто вирвався, були піддані військово-польовому суду. Командир дивізії, начальник штабу, начальник політвідділу та комісар були розстріляні. Загалом репресій зазнали кілька тисяч учасників цієї війни. Повчально, що фінська сторона впорядкувала могили загиблих радянських бійців. У місті Суомуссалмі встановлено монумент воїнам 44-ї дивізії, в той час, коли на Батьківщині були забуті імена героїв.

Ключові слова: зимова, блискавична війна 1939-1940 рр., українці на захисті Фінляндї

\section{Soviet-Finnish War}

\section{Svetlana Donchenko, Dniprovsk State Technical University}

The whole period of the Soviet Union's existence and the first years of independence of Ukraine did not write and talked about the military conflict in the winter of 1939-1940. The reason for the strategic defeat of the huge Soviet Union in the war with a small Finland. In the Soviet Union, they tried to create such a notion as the «Soviet people,» the relocation and mixing of a large number of people throughout the space of the USSR. Therefore, no one has ever defined participants in events by nationality or territorial location. Ukrainians also did not stand out. It was only when Ukraine became independent that there was a need to determine the participation of Ukrainians in the Soviet-Finnish war and their role. During the Soviet-Finnish war, the North-West front was commanded by the future Marshal and Hero of the Soviet Union, Ukrainian Timoshenko Semyon Konstantinovich. Future Marshal and Hero of the Soviet Union, Ukrainian Kulik Grigory Ivanovich, as Deputy People's Commissar for Defense of the USSR, participated in the preparation of Army and Artillery Parts for the Soviet-Finnish War. The commander of the 70th division was Ukrainian Kirponos Mikhail Petrovich. Participated in the combat operations of the pilot-as and Hero of the Soviet Union, Ukrainian Kravchenko Grigory Panteleevich. Future Marshal and Hero of the Soviet Union, Ukrainian, Moskalenko Kirill Semenovich, during the Soviet-Finnish War, was the head of the artillery 51st Perekopskaya Rifle Division of the Odessa Military District. The future Colonel-General of the Tank Army and Hero of the Soviet Union, Ukrainian Kravchenko Andriy Grigorievich, during the war, was Chief of Staff of the 173th Motorized Infantry Division. In the three- 
month conflict, nearly 40,000 Ukrainians died. Among those who fought in this war and received the highest award - the Order of Lenin - Vasyl Petrenko from Poltava region. On the side of the USSR two divisions participated in the war, which were completed in Ukraine. These are the 44th and 70th Infantry Divisions. The first of them fell into the environment and almost all died, trying to break away from the Finnish ring. Those who escaped were subjected to a martial law court. Division commander, chief of staff, chief of the police department and commissar were shot. In general, several thousand participants in this war suffered repressions. Instructive that the Finnish side arranged the graves of the dead Soviet soldiers. The city of Suomussalmi has a monument to the soldiers of the 44th Division, at the time when the names of the heroes were forgotten in the homeland.

Keywords: winter, Soviet-Finnish war, lightning war of 1939-1940, Ukrainians on the defense of Finland

\section{Советско-финская война}

\section{Светлана Донченко, Днепровский государственный технический университет}

Весь период существования Советского Союза и первые годы независимости Украины никто не писал и не говорил о военном конфликте зимой 1939-1940 гг. Причина в стратегическом поражении огромного СССР в войне с маленькой Финляндией. В Советском Союзе пытались создать такое понятие, как «советский народ», происходило переселение и смешение большого количества людей на всем пространстве СССР. Поэтому никто никогда не определял участников событий по национальности или территориальному расположению. Не выделялись и украинцы. Только когда Украина стала независимой, возникла необходимость выяснить участие украинцев в советско-финской войне и их роль. Во время советско-финской войны Северо-Западным фронтом командовал будущий Маршал и Герой Советского Союза, украинец Семён Константинович Тимошенко. Будущий Маршал и Герой Советского Союза, украинец Григорий Иванович Кулик, как заместитель наркома обороны СССР, участвовал в подготовке армейских и артиллерийских частей к советско-финской войне. Командиром 70-й дивизии был украинец Кирпонос. Принимал участие в боевых действиях летчик-ас и Герой Советского Союза, украинец Григорий Пантелеевич Кравченко. Будущий Маршал и Герой Советского Союза, украинец Москаленко, во время советско-финской войны был начальником артиллерии 51-й Перекопской стрелковой дивизии Одесского военного округа. Будущий генерал-полковник танковых войск и Герой Советского Союза, украинец Андрей Григорьевич Кравченко, во время войны был начальником штаба 173-й мотострелковой дивизии. В трехмесячном конфликте погибло почти 40000 украинских. Среди тех, кто воевал в этой войне и получил высшую награду - орден Ленина - Василий Петренко с Полтавщины. На стороне СССР в войне участвовали две дивизии, которые комплектовались в Украине. Это 44-и 70-я стрелковые дивизии. Первая из них попала в окружение и почти вся погибла, пытаясь вырваться из финского кольца. Те, кто вырвался, были подвергнуты военно-полевому суду. Командир дивизии, начальник штаба, начальник политотдела и комиссар были расстреляны. В общем репрессиям подверглись несколько тысяч участников этой войны. Поучительно, что финская сторона упорядочила могилы погибших советских бойцов. В городе Суомуссалми установлен монумент воинам 44-й дивизии, в то время, когда на родине были забыты имена героев.

Ключевые слова: зимняя, советско-финская война, молниеносная война 1939-1940 г2., украинцы на защите Финляндии

\section{Постановка проблеми.}

3 30 листопада 1939 по 13 березня 1940 рр. під час боїв у Фінляндії майже повністю загинули бійці 7-мої Чернігівської стрілецької та 44-ої Київської стрілецької дивізії, по чверті особового складу втратили інші дивізії, сформовані в Київському, Харківському та Одеському військових округах. За даними, які вимагають додаткового дослідження, у фінській війні загинуло щонайменше 40 тис. вихідців з України, десятки тисяч залишилися інвалідами або померли від ран $[2,3]$.

Сьогодні багато пишуть про Росію як країну-агресора. I не лише сучасна Російська Федерація брала участь у війні з Грузією, нині - з Україною і Сирією. Дуже важливо, що скрізь гинуть не лише військові з обох боків, російські війська ведуть прицільний вогонь по мирних жителях. Власне, подібні війни вели і Російська імперія, і Радянський Союз. Військових конфліктів за участю СРСР було багато у XX сторіччі. 
Одним із «конфліктів», як його називали в радянській історіографіі, була і радянсько-фінська війна. Фактично вона продовжувалася трохи більше трьох зимових місяців, тому й отримала назву «зимова».

Аналіз досліджень і публікацій.

В радянській та пострадянській історіографії «зимова війна» згадується як окремий локальний конфлікт, у відриві від контексту Другої світової війни. У деяких радянських підручниках про неї взагалі немає жодного рядка, на відміну від конфлікту на Халхін-Голі.

Проте у 60-ті роки, в період «відлиги», ситуація корінним чином змінилася, чого не скажеш про загалом радянське та сучасне російське бачення тих подій.

Радянсько-фінська війна для радянської та й пострадянської історіографії була і $є$ одним 3 найбільш міфологізованих воєнних конфліктів першої половини XX ст. Причина - провал «бліц-кригу» Червоної армії на Карельському перешийку.

Дуже довго матеріали про цю війну приховувалися із-за невдач Червоної Армії. Тому в сучасній історіографії іiі називають «невідомою» або «непотрібною війною».

В наш час проблеми радянсько-фінської війни вивчають і українські історики, які намагаються встановити роль і участь українців у цій війні. Так, Гриневич В. А. досліджував особливості цієї гібридної війни та участь в ній українців. Ковальов Д. В. розглянув існування «Фінляндської Народної Республіки», як більшовицьку авантюру, яка мала історичне продовження. Жежера В. звернувся до вивчення кількості загиблих українців та радянських військ в цілому. Городянин-Лісовський Ю. описав роль українців у припиненні сталінської агресії у Фінляндії тощо.

Але досі не встановлена повна кількість українців - учасників цієї війни, їх роль у подіях та кількість загиблих, померлих від ран та репресованих після війни. Адже ніколи в СРСР не виділяли національності, окрім російської. Дуже часто при заміні документів робилася помилка, і людина замість українського прізвища отримувала російське, а переправляти помилку було «неможливо». В науковій літературі описані такі приклади: один із них, як замість українського прізвища Романів людина отримала російське - Романов.

Мета дослідження. Наша мета - узагальнити розрізнені дані про воїнів-українців, визначи- ти, що ще недосліджене для продовження вивчення цієї теми.

\section{Виклад основного матеріалу.}

Причиною війни було те, що вже відбувся розподіл територій між Німеччиною і Рaдянським Союзом відповідно до таємного протоколу до «Пакту про ненапад» 23 серпня 1939 р., за яким територія Фінляндії також увійшла до сфери впливу СРСР, та «Договір про дружбу і кордон» між СРСР та Німеччиною від 28 вересня 1939 р.

На той момент радянські війська вже увійшли до Західної України, Західної Білорусі і Прибалтійських країн. Розуміючи, що Гітлер скоро направить свої війська на кордони СРСР, Й. Сталін звернувся з пропозицією до Фінляндії змінити кордони у Карелії в районі м. Ленінград. Взагалі це нонсенс, звернутися до іншої держави 3 вимогою віддати свою промислову територію в обмін на неосвоєну. Як можна взагалі віддати свою територію іншій державі? Це повна неповага до Фінляндії і іiі недооцінка. Відома фраза Й. Сталіна: «Поскольку Ленинград передвинуть нельзя, придётся отодвинуть от него подальше границу». Недооцінка Фінляндії була ще в одній фразі Й. Сталіна: «Мы произведем только один выстрел, и финны сразу поднимут руки и сдадутся» [11].

Другою причиною було те, що серед радянських політичних діячів була більшість таких, що не вважали Фінляндію незалежною державою. Й. Сталін неодноразово підкреслював, що незалежність Фінляндії «було надано» у 1917 р. більшовицькою владою, але Радянський Союз «поки що терпить» суверенну Фінську державу [10].

Але між Фінляндією та СРСР було підписано угоду про мирне співіснування терміном на десять років і фіни, в цілому, розглядали ії як певну гарантію миру. Це дуже нагадує «Пакт про ненапад», коли між Німеччиною та СРСР було укладено пакт на 10 років, і він також розглядався Й. Сталіним як гарантія. Потім був напад 22 червня 1941 р. без оголошення війни.

Треба відзначити, що «Пакт про ненапад», укладений між радянським та фінським урядами 1932 р., залишався діючим до кінця Другої світової війни.

Спочатку Фінляндії було запропоновано передати острів Ханко для розташування на ньому радянської військово-морської бази, пропонуючи взамін значно більшу територію. Зрозуміло, що це викликало протест 
в уряді Фінляндії і він відмовився від такої пропозиції [2].

Зрозуміло, що Й. Сталін був роздратований, оскільки він давно виношував ідею відновлення імперії і повернення усіх земель, в тому числі й Фінляндії, які входили до колишньої Російської імперії.

Це також нагадує сучасні події, коли Російська Федерація виступила гарантом недоторканості незалежної України і перша напала не неї. Можна 3 певністю говорити, що В. Путін продовжує політику Й. Сталіна та А. Гітлера.

Дещо пізніше Радянський Союз уже офіційно оголосив свої претензії. Тодішній голова радянського уряду та народний комісар закордонних справ В. Молотов запросив фінську делегацію провести переговори у Москві 12 жовтня 1939 р. А перед цим, у вересні-жовтні 1939 р., вже почалося розміщення радянських військ вздовж радянсько-фінського кордону.

На цей раз радянські вимоги були більш значними та деталізованими. Було знову висловлено, що Ленінград може опинитися у скрутному становищі, якщо розпочнеться війна. Тому СРСР вимагав укріплення та озброєння Фінляндією Аландських островів під наглядом радянських військових. Знову Радянський Союз вимагав в оренду півострів Ханко на тридцять років iз розташуванням на ньому радянських військових баз. Окрім того, була вимога передати СРСР майже дві з половиною тисячі квадратних кілометрів фінської території на Карельському перешийку, щоб відсунути сухопутний кордон від Ленінграду. Натомість Фінляндія могла отримати більше п'яти тисяч квадратних метрів радянської території на півночі Карелії. Фактично, Фінляндія за цим планом ставала повністю залежною від СРСР.

Зрозуміло, що реакція Фінляндії була вкрай негативною: по-перше, це створювало загрозу нейтралітету і незалежності Фінляндії та iï столиці Гельсінкі; по-друге, територія, яку хотів отримати Радянський Союз, була однією 3 найбільш промислово розвинених у Фінляндії 3 другим за значенням містом Віїпурі. А та територія, яку пропонував СРСР Фінляндії, абсолютно нерозвинена; по-третє, на Карельському перешийку були розташовані основні оборонні споруди Фінляндії, без них країна ставала вразливою для ворога.

Незважаючи на весь негатив пропозицій СРСР, Фінляндія погодилась на обмін кількох островів на аналогічну територію в Карелії. Нова незгода Радянського Союзу примусила фінську делегацію відбути 3 переговорів для консультацій на батьківщині [10].

Радянський Союз вже був готовий до нападу на Фінляндію. Але просто так напасти на мирну країну було неможливо, тому треба було знайти привід. I таким приводом для початку війни послужив обстріл селища в прикордонній зоні на території СРСР. В ніч з 26 на 27 листопада 1939 р. секретний підрозділ НКВС, таємно перейшовши державний кордон, здійснив артилерійський обстріл прикордонного селища Майніла з території Фінляндії. Ця провокація була влаштована радянською стороною, щоб розпочати денонсацію договору із Фінляндією проненападзметоюподальшогоїїзагарбання. А 29 листопада 1939 р. СРСР розірвав дипломатичні стосунки з Фінляндією. Офіційно війну так і не було оголошено (знову звертаємо увагу на схожість поведінки Й. Сталіна і А. Гітлеpa, який також розпочав війну проти СРСР без оголошення).

Якщо можна сказати «у відповідь», 30 листопада 1939 р., війська Ленінградського військового округу за підтримки артилерії з кораблів Балтійського і Північного флотів розпочали наступ. Водночас радянська авіація бомбардувала 20 фінських міст, унаслідок чого було вбито і поранено кілька тисяч мирних жителів (підкреслюємо мирних жителів, а не військових). Адже залякати мирних жителів простіше, ніж воювати з армією $[2,13]$.

Згідно з планами Генерального штабу Червона армія одним ударом повинна була розбити фінські війська та зайняти всю територію країни, і вийти до кордонів Швеції за кілька днів, i приєднати іiї до СРСР (це так звана «блискавична війна»).

Як результат, Ліга Націй вимушена була визнати СРСР агресором і виключити зі свого складу. Цей факт в радянській історії ніколи не оприлюднювався і не коментувався [11].

Ще одне: відносно Фінляндії Й. Сталін вирішив піти шляхом, який потім буде використовуватися по відношенню до інших країн Свропи - виникла ідея створення «Народного уряду» Фінляндії. Було вирішено утворити на території СРСР в містечку Терійокі (нині м. Зеленогорськ Ленінградської області) Фінляндську Демократичну Республіку. Тобто з'явилося дві Фінляндії, говорячи мовою того періоду - радянська i буржуазна. Тож, офіційно, Радянський Союз 3 Фінляндією не воював, а допомагав «червоним» 
фінам у боротьбі з білофінами. Уряд новоствореної маріонеткової «держави» був утворений на базі керівництва заснованої ще у 1918 р. в СРСР у Москві Комуністичної партії Фінляндії (так само у 1918 р. у Москві була створена Компартія України, яка потім створила Лівобережну державу і увійшла до складу СРСР). На чолі уряду, партії і нової «держави» Й. Сталін призначив відомого «червоного фіна», члена Виконкому Комінтерну Отто Віллє Куусінена. СРСР терміново визнав «уряд» О. Куусінена і уклав з ним новий «договір про дружбу» $[4,5]$.

Відповідно, новій державі необхідна була своя армія - фінська дивізія. Але напередодні пройшло в СРСР декілька хвиль етнічних чисток та репресій проти інгерманландців, карелів, фінського населення, фінських комуністів. Тому для створення такої армії збирали людей таких, щоб були схожі на фінів: білявих, північних блондинів, більшість із яких були білорусами). Так виникла «Народна Армія Фінляндії». Потім цей досвід буде використано при створенні польської «Армії крайової», французького авіазагону і тому подібне. Після початку радянського етапу Другої світової війни з Німеччиною влітку 1941 р. підрозділи цієї «армії» були передані радянським військам на фронтах, а після закінчення Другої світової війни всіляка інформація про іiі існування була в СРСР засекречена $[4,5]$.

Більша за кількістю та краще озброєна Червона армія, маючи велику перевагу танків та артилерії, дуже швидко почала просуватися вперед. Фінська армія відступала, не маючи в необхідній кількості протитанкових засобів. Радянські історики писали про те, що практично всі війни Росія починала 3 поразок і причин було багато. У цій війні одразу далася взнаки неузгодженість дій радянських військ - артилерія та авіація діяли окремо від піхоти, танки використовувалися неефективно.

В цих умовах фіни не кинули напризволяще своїх людей (на відміну від уряду Й. Сталіна, який кинув мирних жителів, в тому числі й українців, на окупованій фашистами території), а терміново і дуже організовано розпочали евакуацію мирного населення 3 небезпечних районів, при відступі ретельно мінували територію, почала діяти велика кількість лижних загонів, чого не було у радянських військах. Фінські лижники були добре обізнані з місцевістю і зненацька атакували колони нападників, добре замасковані снайпери завдавали величезних втрат Червоній Армії.
У війну вступило також «Державне управління спиртних напоїв» Фінляндії, яке взялося за масове виготовлення пляшок із запалювальною сумішшю - саме фіни назвали цей витвір коктейль Молотова.

Допомогла фінам і погода. Раптово стало дуже холодно. Нагадаємо, що це мала бути коротка, блискавична війна. Тому червоноармійці були вдягнені у літню форму і не готові до зимових боїв, радянське рушничне мастило на морозі тверділо, акумулятори вантажівок виходили $з$ ладу. Знову нагадує напад фашистів на СРCP [10].

Оборона Фінляндії здійснювалася дисциплінованими, грамотно керованими солдатами, що звикли до місцевих кліматичних і погодних умов, і застосовували тактику, відповідну цим умовам. Радянський же наступ був спланований без урахування характеру місцевості, погодних умов і відповідних проблем постачання (нагадує російсько-японську війну 1904-1905рр.).

Загалом воєнні дії тривали 105 днів. За цей час Червона армія втратила за різними оцінками від 422 до 722 тисяч убитими, пораненими, обмороженими й полоненими (в радянських дослідженнях цифри дуже різняться: називається початкова цифра і 130 тис., і 422 тис.), у фінському полоні опинились до 6000 осіб, у тому числі понад 300 командирів, 17 тис. чоловік зникли безвісті. Втрати СРСР становили до $40 \%$ бойового складу задіяних частин і суттєво переважали втрати фінської сторонни. Причому ті 6 тис. червоноармійців, які потрапили у полон і пізніше були передані радянській стороні, зазнали репресій з боку сталінського режиму: майже 700 iз них як «зрадників» засудили до смерті, 4,5 тис. відправили до концтаборів. У своїх мемуарах, складених у 70-тих роках, М. Хрущов називав цифру навіть у мільйон загиблих... [11]

На підставі радянських невдач А. Гітлер і його генерали припустили, що у Радянського Союзу неефективне керівництво, тактика й озброєння, і він не виявиться гідним супротивником для німецької військової машини. Недарма Гітлер у своїй книзі «Моя боротьба» назвав СРСР - «колосс на глиняних ногах». Цю думку поділяли і багато хто з іноземних спостерігачів, в тому числі і міністерство оборони США.

Чималу роль відіграли у цій війні українці. Під час радянсько-фінської війни Північно-Західним фронтом командував майбутній Маршал і Герой Радянського Союзу, українець Тимошенко Семен Костянтинович. Його 
війська здійснили прорив лінії Маннергейма у лютому 1940 p.

Майбутній Маршал і Герой Радянського Союзу, українець Кулик Григорій Іванович, як заступник наркома оборони СРСР брав участь у підготовці армійських і артилерійських частин до радянсько-фінської війни. Був репресований і розстріляний в $1950 \mathrm{p}$.

Командиром 70-ї дивізії був українець Кирпонос Михайло Петрович. За вміле командування дивізією і проявлений героїзм Михайло Кирпонос був удостоєний звання Героя Радянського Союзу (1940 р.).

Приймав участь в боях льотчик-ас і Герой Радянського Союзу, українець Кравченко Григорій Пантелійович, уродженець Голубівки Дніпропетровської області.

Майбутній Маршал і Герой Радянського Союзу, українець Москаленко Кирило Семенович, під час радянсько-фінської війни був начальником артилерії 51-ї Перекопської стрілецької дивізії Одеського військового округу, був нагороджений орденом Червоного Прапора.

Майбутній генерал-полковник танкових військ і Герой Радянського Союзу, українець Кравченко Андрій Григорович, під час війни був начальником штабу 173-ї мотострілецької дивізії [12].

Як стверджують дослідники, у трьохмісячному конфлікті загинуло майже 40 тисяч українців [3]. Серед тих, хто воював у цій війні та отримав найвищу нагороду - орден Леніна - Василь Петренко з Полтавщини [9].

Зрозуміло, що військові з УРСР також брали участь у війні. Дві дивізії, які комплектувались в Україні, це 44-та та 70-та стрілецькі дивізії. До війни місцем дислокації 44-ої Щорсівської дивізії був Житомир, і дивізію перекинули звідти на північ, не видавши ані теплих кожушків, ані валянок, ані рукавиць. Ніч із 3 на 4 січня 1940 року стала однією з найхолодніших (до 4550 градусів морозу).

Ветеран Фінської кампанії Григорій Геращенко згадував:

«Тепліше обмундирування мало командування, політруки, льотчики й танкісти: у них були кожухи, ватні фуфайки, валянки... Для піхотинців же це вважалося великою розкішшю. Мовляв, у важких кожухах незручно йти в атаку й на штурм.

У бій ішли в сірих вовняних шинелях, бавовняних гімнастерках, байковій білизні, ватяних рукавицях. У шоломах-будьонівках із напів- шерстяною підкладкою... На ногах - обмотані ганчір'ям черевики.

А їжа! Хліб прибував на передову у вигляді мерзлої цеглини, така ж каша, ледь теплий чай» [2].

37 на 8 січня 1940 р. 44-та дивізія (чисельністю близько 17, 5 тисяч чоловік) була повністю розбита. Втрати особового складу дивізії перевищили $70 \%$, близько 1200 бійців й командирів попало в полон.

44-та дивізія, згідно з першим планом, повинна була діяти на лівому фланзі, тобто на Кухмо-Каяані, оскільки він був обраний для нанесення головного удару.

Проте з 15 грудня в силу нових обставин ця дивізія повертає на центральний напрямок на Ухту на допомогу 163-тій дивізії. Тепер там планувалось нанести основний удар.

Вже 28 грудня наступ 163-ї було зламано. Велика частина особового складу дивізії відступила на північний схід вздовж озера Киантаярві (i це тоді, коли 44-та дивізія знаходилась на відстані всього 10 кілометрів). Залишки дивізії перегрупувались для оборони в районі Юнтусранта.

Тим часом полковник Сііласвуо всі сили, що були в його розпорядженні, спрямував на оточення й знищення 44-ої дивізії [13].

Щорсівці, рухаючись на з'єднання з 163-ою, сильно розтягнулись й опинились затиснутими між лісами й болотами на дорозі Раате. Фіни, прекрасно орієнтуючись в цій місцевості, кожного дня влаштовували завали 3 дерев на шляху просування дивізії.

Сапери-червоноармійці рухалися в кінці колони й не могли вчасно розчищати дорогу. Стало неможливим відправити в тил поранених і хворих (фінам таки вдалося перерізати сполучення дивізії). До того ж фіни знищили прикордонний міст, тим самим повністю відрізавши дивізію від тилових комунікацій.

Становище щогодини погіршувалося. Внаслідок ударів фінських частин з 30 грудня 1939 по 4 січня 1940 pp. 44-а дивізія була розчленована на шість окремих осередків опору. Щорсівська дивізія опинилась в оточенні фінів і програла в боях впродовж 1-7 січня $1940 \mathrm{p}$.

4 січня О. Виноградов доповідав штабу 9-ої Армії: «...Противник зосереджує свої сили, щоб перерізати оборону дивізії. У зв'язку з відсутністю продфуражу настрій поганий, коні дохнуть, бензину та боєприпасів майже немає...» [6].

Героїчний опір фінів, небажання ставати «союзною республікою», на їхню думку, були 
зумовлені тим, що фінський народ добре знав, до чого призвела масова колективізація в СРСР та Україні зокрема.

Почалася деморалізації бійців 44-ої дивізії. Цьому сприяло також те, що їм рідко коли вдавалося побачити мертвого фінського солдата (фіни мали чіткий наказ забирати з поля бою всіх своїх полеглих бійців), в той час як червоноармійці, рятуючись від лютого холоду, були змушені влаштовувати собі схованки з трупів загиблих і замерзлих однополчан.

Як згадують очевидці тих страшних подій, розстрілявши 3 кулемета фінського снайпера, який влаштувався неподалік на дереві, радянські солдати відразу ж кинулися до місця його падіння. Проте замість трупа знайшли лише сліди від крові та двох пар лиж, які зникали в гущавині лісу [12].

В середині грудня фінам вдалося перехопити ініціативу й завдати болючих контрударів по радянським військам. Саме тоді сталися відомі події розгрому 44-тої дивізії, що їх охрестили «Драмою при Суомусалмі».

Загалом фінські війська втратили під Суомусалмі близько 800 чоловік, радянські (163 та 44 дивізії) - не менше 23 тисяч! Окрім того, 44-та дивізія була моторизованою, тому до рук фінів потрапило багато трофейної техніки: 43 танки, 270 автомобілів та тракторів, а також 300 кулеметів й 6000 гвинтівок. Повчально, що фінська сторона впорядкувала могили загиблих бійців 3 України. У місті Суомуссалмі встановлено монумент воїнам 44-ї дивізії [7].

Залишки дивізії, що вирвались 3 оточення, склали всього 1050 чоловік, які зайняли оборону на відрізку дороги, що вела до Суомусалмі, в 9 км від кордону. Ті, кому пощастило вижити, одразу потрапили до рук НКВС.

Бойові дії активізувалися у лютому 1940 р., коли радянській стороні вдалося зосередити на радянсько-фінському фронті понад 760 тис. військовослужбовців. У складі десятків частин i з'єднань, що їх перекинули з Київського, Харківського та Одеського військового округів, було багато мешканців УРСР [2].

У середині лютого 1940 р. 35 дивізій Північно-західного фронту (командувач С. Тимошенко) подолали головну смугу фінської оборони на Карельському перешийку, зламали спротив 15-ти дивізій фінської армії і на початку березня 1940 р. фактично завершили прорив «лінії Маннергейма».
Будучи не в силах продовжувати опір, Фінляндія погодилася на укладення мирного договору, який був підписаний у Москві 12 березня 1940 р. Але бойові діï за Виборг ще тривали 13 березня. До СРСР перейшли Карельський перешийок, низка островів у Фінській затоці та ін. (31 березня 1940 р. із цих територій, а також Карельської АРСР була створена Карело-Фінська PCP) [4].

Таким чином, 44-а стрілецька дивізія потрапила в оточення і майже вся загинула, намагаючись вирватись 3 фінського кільця. Ті, хто вирвався, були піддані військово-польовому суду. Командир дивізії, начальник штабу, начальник політвідділу та комісар були розстріляні. Загалом репресій зазнали кілька тисяч учасників цієї війни.

Загиблим українцям присвячені другий та третій томи 3 серії «Загиблі на чужині», які під назвою «Полягли в снігах Суомі» випустило видавництво «Книга пам’яті України», вони містять інформацію про відповідно 9000 і 18000 осіб [12].

Українські підрозділи з українців-мігрантів, що воювали на боці Фінляндії, фактично, продовжували боротьбу проти СРСР, яку розпочали, покинувши Україну. Інша справа - радянські полонені, що також воювали на боці Фінляндії і були сформовані у 1940 р. Вони пережили в Україні голод 1921-1022 рр., та голодомор 19321933 рр., і їм не хотілося захищати СРСР, який знищував жителів України.

До певної міри низька боєздатність пояснювалася тим, що перекинуті з України підрозділи здебільшого не були належним чином екіпіровані для ведення боїв при дуже низьких температурах. Крім того, на відміну від фінських вояків, червоноармійці здебільшого погано вміли користуватися лижами, а тому були прив'язаними до доріг і менш мобільними.

Відтак чимало червоноармійців, зокрема й українців, потрапило в полон. Причому фінська сторона намагалась обіграти цю ситуацію у своїй пропаганді, розповсюджуючи листівки 3 фото, 3 яких випливало, що полонених утримують у хороших умовах і добре годують. «Поширення цих фото викликало певне озлоблення в радянського керівництва. Адже виглядало так, що радянські люди у полоні себе добре почувають: не страждають, не б'ються і не намагаються втекти», каже Максим Майоров [13]

У радянських полонених, що воювали на боці Фінляндіï, на озброєнні була фінська та 
радянська зброя. Однострої були фінськими 3 чорними кашкетами із синьо-жовтою околицею і тризубом, хоча в багатьох випадках українські добровольці продовжували носити радянську форму, доповнюючи іiі мазепинками. Синьо-жовті армійські відзнаки не вживалися, оскільки такі мали добровольці зі Швеції.

Відомо також, що вести агітацію серед військовополонених українців та сформувати із них підрозділ на фінському боці мав намір письменник Юрій Горліс-Горський, який свого часу був офіцером армії УНР. Утім, судячи із залишених ним нарисів, він прибув до Фінляндії вже після закінчення війни, а тому не міг взяти участь у бойових діях, вважає Максим Майоров [13].

Інші вважають, що Ю. Горліс-Горський був одним із найвідоміших командирів українських добровольців у Фінляндії. Добре відомо, що ефективний український полк на чолі із Юрієм Горліс-Горським був задіяний на Карельському перешийку на початку березня 1940-го р. Бійці цього загону знищували більшовицьких окупантів методами запорозького козацтва та холодноярських повстанців - із заздалегідь приготованих засідок бійці здійснювали атаку «лавою», головною метою бою було виснаження супротивника та його деморалізація, тож 3 цією метою в таборі створювався резерв, який у вирішальний момент мав завдати раптового удару. Охоплення ворога $з$ флангів, вихід йому в тил попри відмінність карельського ландшафту від українського, створення резерву та засідки, раптовість удару та вміле використання рельєфу болотистої та лісистої місцевості фінської Карелії стали характерними ознаками військового мистецтва українських добровольців [1].

Ось що писав командарм радянської 7-ї армії, яка штурмувала Карельський перешийок в лютом-березні 1940 р., командувач військами Ленінградського військового округу К. Мєрєцков [збережено мову оригіналу]: «Прорвав главную полосу к концу февраля, мы преодолевали на протяжении нескольких километров отсечные позиции, за которыми натолкнулись на новую оборонительную полосу, где, как мне доложили наши разведчики, засели не весть откуда взявшиеся националистические банды хохляцких эмигрантов-перебещиков. В начале марта 1940 г., я получил донесение о крахе 9-й армии в цетральной Карелии, где 44-я дивизия, напрочь состоявшая из выходцев с Советской Украины, была не столько уничтожена, сколько взята в плен. Как оказалось позже, хохлы не хотели во- евать за нашу Советскую Родину и поэтому массово сдавались в белофинский плен. Уже в самой Финляндии им предлагали стать добровольцами в националистической банде для переброски на Карельский перешеек и сдерживания нашей атаки под Выборгом...» [8].

Інформацію про українців у складі Фінської армії до військового командування «Червоної армії» та партійного керівництва ВКП(б) доповідали завербовані агенти з числа фінських комуністів. Уряд Кремля знаючи про масову здачу у фінляндський полон українських червоноармійців вирішив припинити війну, адже масштабна втеча вояків зі зброєю на бік ворога могла зіграти поганий жарт 3 дисципліною у всіх інших боєздатних підрозділах «Червоної армії» [10].

Як і в Першу світові війну, постала унікальна ситуація - українці опинились по обидва боки фронту. I саме українці стали тим небезпечним каталізатором падіння морального і бойового духу в рядах Червоної армії. Продуктивна діяльність українського полку під проводом Юрія Горліс-Горського стала загрозою для подальшої військової ескалації Кремля напередодні справжної м'ясорубки - Другої світової війни у Європі. Співпраця Юрія Горліс-Горського $з$ фінськими націоналістами довела урядовцям в Гельсінкі, що попри радянську окупацію бойовий дух української нації залишається незламним.

$\mathrm{Ti}$, кому пощастило вижити, одразу втрапили в руки НКВС. Цей документ наведемо повністю:

«Цілком таємно: Начальнику Генерального штабу Червоної Армії т. Шапошникову (для ставки)

Доповідаємо: суд над колишнім командиром 44 СД Виноградовим, начальником штабу Волковим й начполітвідділу Пархоменком відбувся 11 січня під відкритим небом в присутності особового складу дивізії.

Звинувачувані визнали себе винуватими у скоєних злочинах. Промови прокурорів й громадського обвинувача були схвалені всіма присутніми.

Суд тривав 50 хвилин. Приговор до розстрілу був приведений до виконання негайно публічно взводом червоноармійців.

Після приведення приговору в дію відбулась нарада начскладу, на якій була намічена подальша роз'яснювальна робота. Виявлення всіх зрадників і боягузів продовжується.

В 44 СД працює комісія Воєнради, в обов'язки якої входить детальне розслідування всіх причин і обставин поразки 44 СД.

Чуйков, Мехліс

11 січня 1940 р.» [2]. 
Зимова Війна закінчилась. Попри тактичну перемогу СССР, стратегічно перемогла Фінляндія, хоч і вимушена була поступитись власними територіями - Карельським перешийком, кількома островами у Фінській затоці і частиною північних півостровів (Рибачий та Середній) [2].

3 наведених вище фактичних даних $€$ всі підстави вважати, що саме український фактор призвів до ризику повної деморалізації радянських військ у Фінляндії. Ситуація, за якої одні українці, по суті, уникали активної завзятої війни проти Фінської армії, а інші, з протилежного фронту, надавали їм приклад і можливість воювати на стороні справедливості, могла в наступний момент перерости в тотальну катастрофу сталінської вояччини. Скоріше всього, усвідомлення навислої над більшовицьким військом загрози повної деморалізації й змусило Й. Сталіна зупинити війну в Фінляндії. Адже йому було байдуже до чисельних втрат особового складу Червоної армії, він би міг покласти стільки життів, скільки було б потрібно для окупації всієї країни, але Й. Сталін побоявся ризикнути морально-бойовим духом своїх військ перед запланованою на наступний рік великою європейською кампанією. I саме українські воїни по обидва боки фінського фронту створили ці ризики для Москви й тим самим захистили, можливо, не тільки Фінляндію, а й інші Скандинавські країни, й тим самим запобігли домінуванню радянської імперії у всьому Балто-Скадинавському регіоні! [7]

\section{Висновки.}

Внесок українського полку під проводом Юрія Горліс-Горського у «зимовій війні» важко переоцінити, адже тривалий час кремлівської пропаганди та навмисного забуття зробили свою справу - про українських добровольців забули на довгі десятиліття. Однак, радянська доба скінчилась, незалежна Україна існує так само, як і самостійна Фінляндія, a от московський «колосс» на глиняних ногах все ж зазнав краху, про що свідчить і сьогоднішня путінська агонія. Сталінська агітація та партійна пропаганда не згадували про українських добровольців у Фінській армії, бо радянські урядовці не хотіли розголосу і боялись, що «раби-хохли» почнуть не стільки здіймати нові національні бунти і повстання, скільки здаватись у полон ворогам Москви і повертати багнети в бік більшовиків. Так само й історики по обидва боки кордону не наважуються говорити правду про участь українців на боці Гельсінкі, а не тільки Москви. Це стає зрозумілим 3 погляду на сучасну геополітичну ситуацію у Європі. Але українці пам'ятають героїчний вчинок своїх предків, Європа також повинна дізнатися і згадати своїх українських рятівників, які боролися за справедливість, за загальнолюдські цінності.

Але ця тема вимагає продовження вивчення, оскільки багато фактів залишаються невстановленими.

\section{БІБЛІОГРАФІЧНІ ПОСИЛАННЯ}

1. Городянин-Лісовський Ю. (2016). Як українці зупинили сталінську агресію у Фінляндії / Ю. Городянин-Лісовський. - Режим доступу: http://sichovyk.com. ua/istorichna-slava/619-jurij-horlis-horskij-talvisodassa

2. Гриневич В. А. Радянсько-фінляндська війна 1939-1940 / В. А. Гриневич // Енциклопедія історії України: у 10 т. - Київ: Наук. думка, 2012. - Т. 9. - С. 121. ISBN 978-966-00-1290-5.

3. Жежера В. У Фінляндії загинуло більше, ніж в Афганістані / В. Жежера // «Gazeta.ua.». - 2012. - 4 грудня.

4. Карело-Фінська РСР. - Режим доступу: http:// territoryterror.org.ua/uk/resources/calendar/ details/ ?newsid=533. 5. Ковальов Д. В. «Фінляндська Народна Республіка» як більшовицька авантюра / Д. В. Ковальов. // Полілог: збірник наукових праць. - 2016. - Вип. 3. - С. 11-22.

6. Ковальов Д. В. Бій при Хонканіємі (перший бойовий досвід фінляндських танкових військ) / Д. В. Ковальов // Історичні етюди: збірник наукових праць. - 2011. - Вип. 3. - С. 117-119.

7. Ковальов Д. Як українці зупинили сталінську агресію у Фінляндії / Д. Ковальов, Ю. Якуба. - Режим доступу: https://uk.wikipedia. org/wiki/\%D0\%A0\%D0\%B0\%D0\%B4\%D1\%8F\%D0\%BD $\%$ D $1 \% 81 \% \mathrm{D} 1 \% 8 \mathrm{C} \% \mathrm{D} 0 \% \mathrm{BA}$

8. Мерецков К. А. «На службе народу. Страницы воспоминаний...» / К. А. Мерецков. - М.: Политиздат, 1968. - С. 171-196. 9. Правденко О. Новини / О. Правденко. - Режим дступу: http://archive.kolo.poltava.ua/2013/02/28/poltavecvasil-petrenko-u-finskij-vijnizasluzhiv-orden-lenina

10. Радянсько-фінська війна: завдання - вижити. Три уроки для України. - Режим доступу: http://texty.org.ua/ pg/article/editorial/read/75019/Radanskofinska_vijnazav dannavyzhytyTryuroky

11. Семиряга М. И. Ненужная война / М. Й. Семиряга // Тайны сталинской дипломатии. 1939-1941. - М.: Высш. шк., 1992. - С. 141-204.

12. Український інститут національної пам'яті. - Режим доступу: http://www.memory.gov.ua/news/u-chernigovizgadali-pro-75-richchya-radyansko-finskoi-viini

13. Шурхало Д. Українці в радянсько-фінській війні / Д. Шурхало. - Режим доступу: https://www.Radiosvoboda. org/a/28180903.html 


\section{REFERENCES}

1. Horodianyn-Lisovskyi, Yu. (2016). Yak ukraintsi zupynyly stalinsku ahresiiu u Finliandii [How Ukrainians stopped the Stalinist aggression in Finland]. Retrieved from: http://sichovyk.com. ua/istorichna-slava/619-jurij-horlis-horskijtalvisodassa [in Ukrainian].

2. Hrynevych, V.A. (2012). Radiansko-finliandska viina 1939-1940 [The Soviet-Finnish War 1939-1940]. Entsyklopediia istorii Ukrainy. (Vol. 9). Kyiv: Nauk. Dumka [in Ukrainian]. ISBN 978-966-00-1290-5.

3. Zhezhera, V. (2012). U Finliandii zahynulo bilshe, nizh v Afhanistani [Finland died more than in Afghanistan]. «Gazeta.ua.» [in Ukrainian].

4. Karelo-Finska RSR [Karelian-Finnish SSR]. Retrieved from: http:// territoryterror.org.ua/uk/resources/calendar/ details/ ?newsid=533 [in Ukrainian].

5. Kovalov, D.V. (2016). «Finliandska Narodna Respublika» yak bilshovytska avantiura [«The Finnish People's Republic» as a Bolshevik adventure]. Poliloh: zbirnyk naukovykh prats, 3, 11-22 [in Ukrainian].

6. Kovalov, D.V. (2011). Bii pry Khonkaniiemi (pershyi boiovyi dosvid finliandskykh tankovykh viisk) [The battle at Honkaniemi (the first combat experience of the Finnish armored troops)]. Istorychni etiudy: zbirnyk naukovykh prats, 3, 117-119 [in Ukrainian].

7. Kovalov, D., \& Yakuba, Yu. Yak ukraintsi zupynyly stalinsku ahresiiu u Finliandii [As Ukrainians stopped the Stalinist aggression in Finland]. Retrieved from: https://uk.wikipedia. org/wiki/\%D0\%A0\%D0\%B0\%D0\%B4\%D1\% 8 F\%D0\%BD $\%$ D1\%81\%D1\%8C\%D0\%BA\%D0\%BED1\%84\%D1\%96\%D0\%BD $\%$ D $1 \% 81 \% \mathrm{D} 1 \% 8 \mathrm{C} \% \mathrm{D} 0 \% \mathrm{BA} \% \mathrm{D}$ 0\%B0_\%D0\%B2\%D1\%96\%D0\%B9\%D0\%BD\%D0\%B0_(19 39\%E2\%80\%941940) [in Ukrainian].

8. Mereckov, K.A. (1968). «Na sluzhbe narodu. Stranicy vospominanij...» [«In the service of the people. Pages of memories... »]. Moscow: Politizdat [in Russian].

9. Pravdenko, O. Novyny [News]. Retrieved from: http://archive.kolo.poltava.ua/2013/02/28/poltavec-vasil-petrenkou-finskij-vijnizasluzhiv-orden-lenina [in Ukrainian].

10. Radiansko-finska viina: zavdannia - vyzhyty. Try uroky dlia Ukrainy [Soviet-Finnish War: the task is to survive.

Three lessons for Ukraine]. Retrieved from: http://texty.org.ua/pg/article/editorial/read/75019/Radanskofinska_ vijnazavdannavyzhytyTryuroky [in Ukrainian].

11. Semirjaga, M.I. (1992). Nenuzhnaja vojna [Unnecessary war]. Tajny stalinskoj diplomatii. 1939-1941. Moscow: Vyssh. shk. [in Russian].

12. Ukrainskyi instytut natsionalnoi pamiati [Ukrainian Institute of National Remembrance]. Retrieved from: http:// www.memory.gov.ua/news/u-chernigovi-zgadali-pro-75-richchya-radyansko-finskoi-viini [in Ukrainian].

13. Shurkhalo, D. Ukraintsi v radiansko-finskii viini [Ukrainians in the Soviet-Finnish War]. Retrieved from: https:// www.Radiosvoboda.org/a/28180903.html [in Ukrainian].

\section{Донченко Світлана Павлівна}

Доктор істор. наук, проф.

Дніпровський державний технічний університет 51918, Кам’янське, вул. Дніпробудівська, 2

\section{Donchenko Svitlana}

Full Prof., Dr.

Dniprovsk state technical university

2, Dniprobudivs'ka str., Kamyans'ke, 51918, Ukraine

Email: sveta33lida@ukr.net

Цитування: Донченко С. П. Радянсько-фінська війна / С. П. Донченко //

Науково-теоретичний альманах «Грані». - 2019. - Т. 22. - № 6. - С. 86-95.

Citation: Donchenko, S.P (2019). Radiánsko-fínska viina [Soviet-Finnish War]. Scientific and theoretical almanac «Grani», 22 (6), 86-95. 